\title{
Transition to adulthood of female factory workers: Some evidence from Bangladesh
}

\author{
Sajeda Amin \\ Population Council \\ Ian Diamond \\ Ruchira Tabassum Naved \\ Margaret Newby
}

Follow this and additional works at: https://knowledgecommons.popcouncil.org/departments_sbsr-pgy

Part of the Demography, Population, and Ecology Commons, Family, Life Course, and Society Commons, International Public Health Commons, and the Work, Economy and Organizations Commons How does access to this work benefit you? Let us know!

\section{Recommended Citation}

Amin, Sajeda, lan Diamond, Ruchira Tabassum Naved, and Margaret Newby. 1997. "Transition to adulthood of female factory workers: Some evidence from Bangladesh," Policy Research Division Working Paper no. 102. New York: Population Council. Version of record: https://doi.org/10.2307/172158 


\section{Transition to Adulthood of Female Factory Workers: Some Evidence from Bangladesh}

Sajeda Amin

I an D iamond

Ruchira T. Naved

M argaret Newby

1997 No. 102 


\title{
Transition to Adulthood of Female Factory Workers: Some Evidence from Bangladesh
}

\author{
Sajeda Amin \\ Ian Diamond \\ Ruchira T. Naved \\ Margaret Newby
}

Sajeda Amin is Associate, Policy Research Division, Population Council, New York. Ian Diamond is Dean of Social Sciences, University of Southampton. Ruchira T. Naved is Senior Fellow, Population Council, Dhaka, Bangladesh and Research Coordinator, Save-the-Children (USA). Margaret Newby is Research Student, University of Southampton.

This paper was presented at the Committee on Population's Workshop on Adolescent Sexuality and Reproductive Health in Developing Countries: Trends and Interventions, Washington DC, 24-25 March 1997. 


\begin{abstract}
The rapidly expanding sector of garment manufacturing for export is unusual for Bangladesh in that it employs young, unmarried women in large numbers. This paper examines data from a study on garment workers in Bangladesh to explore the implications of work for the early socialization of young women. For the first time young women are given an alternative to lives where they move directly from childhood into adulthood through early marriage and childbearing. Work creates a period of transition as contrasted with the abrupt assumption of adult roles at very young ages that marriage and childbearing mandate. It is argued that this longer transition creates a period of adolescence for young women working in the garment sector and that some aspects of adolescence have strong implications for the long-term reproductive health of these young women.
\end{abstract}

This material may not be reproduced in any form without written permission from the author. 
Bangladesh is a society that has traditionally been characterized by very early marriage and childbearing. In the early 1970s the average age at marriage was around 16 years. While a move toward later marriage began in the 1980s and was estimated to be 18 years in a 1989 survey (Huq and Cleland, 1990), the expectation for most women was that they would marry in their mid-teens. Marriage was expected not long after menarche (Aziz and Maloney, 1985), at which time women would typically move directly from their own household to that of their husband.

Adolescence is usually defined as a time between the ages of 10 and 19 years when young people are addressing the transition from childhood to adulthood. Although definitions of adolescence vary, it is generally agreed that there are three main aspects of this life stage: demographic and biological; psychological and emotional; and economic. Young people may have taken on the physical characteristics of adulthood but have not yet gained adult psychological, social, and economic skills. In other words adolescence offers an opportunity to experience a period of independence as a biological but not social adult, whether spent in or outside the natal home. During this period people have a chance to acquire the skills necessary for adult life. In the case of traditional Bangladesh where childhood ended suddenly at an early age due to marriage, the opportunity for adolescence was extremely limited.

Two ways in which society may change to offer women the possibility of adolescence are through increased educational opportunities, particularly at the secondary level, and through the opportunity to work outside the home. This paper uses a combination of qualitative and quantitative data to examine the way in which opportunities for labor force participation in the expanding garment manufacturing industry provide a social setting in which some young Bangladeshi women have the opportunity to experience adoles- 
cence. Although after marriage women may return to a state of economic dependence on their families, garment work does offer young women in Bangladesh the opportunity to develop some degree of economic independence that may give them greater autonomy in future life, including in reproductive decisionmaking. As a demographic and biological life stage, adolescence is a time when girls develop the physiological characteristics of women, one of which is reproductive capacity. The most important direct impact of employment is that it creates strong incentives for delayed marriage. Women enter marriage after their reproductive capacity is properly developed and are thus less likely to be exposed to pregnancy and childbearing in the vulnerable ages below 18 years. Adolescence is a period during which, as reproductive capacity develops, young people learn about management of sexuality. Traditionally in Bangladesh female sexuality is managed through early marriage and through the practice of purdah, which controls the nature of interaction between men and women, both social and sexual. However, working in a factory delays marriage and forces a type of interaction between men and women that defines a life stage during which young women are required to address issues of their relations with men in a way that those who marry early in puberty do not have to face. In terms of adolescence as a social stage, working in factory settings with machines instills confidence and a sense of modernity, exposes young women to a different network of peers, and permits exposure to new lifestyles and social networks. The experience of negotiating contracts and wages imparts skills of negotiation with men that may have future implications for women's relations with their husbands. Work also changes attitudes about education and raises the opportunity cost of women's time. Also as a result of the factory experience, garment workers are exposed to information about health and contraception. 
In Bangladesh, factory employment opportunities for women began late relative to those of other Asian countries that have experienced similar developments in their economies. In 1978, some 130 employees of one of the first four garment factories for export production were sent to Korea for management training, many of whom subsequently set up their own enterprises. By 1985 there were 700 factories and in 1995 the manufacturers' association listed some 2,400 registered factories (BGMEA, 1995). Most factories are now locally owned, though some of the largest are joint venture firms with Korean- and Hong Kong-based producers. By 1995, the sector employed around 1.2 million people, 90 percent of them women. These women typically come from poor, very often rural areas and are often young and single when first employed. The garment industry is the first sector that has provided employment to such women and has thus offered them, for the first time, an opportunity for cash employment outside the home.

The paper begins by placing the emergence of factory work for women in Bangladesh in an international context, through a brief comparison of the work patterns of children and young adults. It then considers how young Bangladeshi women are, for the first time, experiencing and managing adolescence through a series of case studies supplemented with data from a large-scale survey of garment workers and their nonworking counterparts. It ends by considering the implications of these experiences for reproductive health. The paper differs from most explorations of the work-reproduction link in that it highlights the significance of formal-sector employment as a motivation for delaying marriage and potentially improving reproductive health, as opposed to the more common approach where work-reproduction associations are investigated in terms of competing demands for mothers' time in the workforce (UN, 1995b). 


\section{PATTERNS OF ADOLESCENT WORK}

While the fact that children and young adults in developing countries in Asia spend considerable time working is not a new phenomenon, formalsector opportunities are new, particularly for young women. In this section we review trends in the expansion of work opportunities as well as legislation designed to limit child labor. This review provides the relevant context for the main theme of the paper: the social and reproductive health implications of young women joining the formal labor force in large numbers. In reviewing patterns of work, the focus is on the transformation of traditional peasant economies by the globalization of production since the 1970s (Christerson and Appelbaum, 1995). In considering the reproductive health implications of garment work and the way in which it creates an adolescent life stage, it is necessary to consider the particular implications of this type of work rather than just the implications of working per se.

\section{Time-use data}

A series of time-use studies conducted in the mid-1970s documented that boys and girls in the developing world contribute significantly to household labor from early ages and that gender specialization begins early in life (Cain, 1977; Nag, White, and Peet, 1977; Jain, 1985; De Tray, 1983; UN, 1995a). By early adolescence, boys and girls assume full adult work roles. Data from Cain's (1977) intensive time-use study in a rural area of Bangladesh are shown in the top row of Table 1. Boys engage in direct incomegenerating work, whereas girls spend time on various categories of household work including cooking, cleaning, and child care. Amin (1997), comparing time-use data between Cain's 1976 study and her own 1991 study, found overall hours spent working in rural areas fell for girls and women 
Table 1 Daily mean hours worked by sex and age in selected developing areas of Asia

\begin{tabular}{|c|c|c|c|c|c|c|}
\hline \multirow{2}{*}{$\begin{array}{l}\text { Country and age } \\
\text { group }\end{array}$} & \multicolumn{2}{|c|}{ Productive } & \multicolumn{2}{|c|}{ Housework } & \multicolumn{2}{|c|}{ Total } \\
\hline & $\overline{\text { Male }}$ & $\overline{\text { Female }}$ & $\overline{\text { Male }}$ & $\overline{\text { Female }}$ & $\overline{\text { Male }}$ & Fema \\
\hline \multicolumn{7}{|l|}{ Bangladesh 1977a } \\
\hline $4-6$ & 1.2 & 0.7 & 0.9 & 1.2 & 2.1 & 1.9 \\
\hline $7-9$ & 3.5 & 1.4 & 1.1 & 3.7 & 4.6 & 5.1 \\
\hline $10-12$ & 6.6 & 1.3 & 0.6 & 5.4 & 7.2 & 6.7 \\
\hline $13-15$ & 8.8 & 2.0 & 0.7 & 7.0 & 9.5 & 9.0 \\
\hline $16-21$ & 8.8 & 1.6 & 0.7 & 7.8 & 9.5 & 9.4 \\
\hline $22-59$ & 8.0 & 1.8 & 1.1 & 7.5 & 9.1 & 9.3 \\
\hline
\end{tabular}

Nepal $1976^{\mathrm{b}}$

$\begin{array}{lcccccc}6-8 & 3.0 & 2.5 & 0.7 & 2.4 & 3.7 & 4.9 \\ 9-11 & 4.8 & 5.8 & 1.7 & 2.6 & 6.5 & 8.4 \\ 12-14 & 5.7 & 6.6 & 1.8 & 3.3 & 7.5 & 9.9 \\ 15-19 & 7.5 & 8.1 & 2.0 & 3.2 & 9.5 & 11.3 \\ 20-29 & 8.8 & 8.4 & 1.6 & 3.7 & 10.4 & 12.1\end{array}$

Java $1976^{\mathrm{c}}$

$\begin{array}{lllllll}6-8 & 1.7 & 1.2 & 1.9 & 2.3 & 3.6 & 3.5 \\ 9-11 & 1.7 & 3.0 & 1.4 & 2.4 & 3.1 & 5.4 \\ 12-14 & 3.2 & 4.7 & 1.5 & 4.0 & 4.7 & 8.7 \\ 15-19 & 7.6 & 6.5 & 0.3 & 3.7 & 7.9 & 10.2 \\ 20-29 & 8.3 & 7.1 & 0.4 & 4.9 & 8.7 & 12.0\end{array}$

Malaysia $1976^{d}$

\begin{tabular}{lllllll}
$5-6$ & 0.4 & 0.2 & 0.2 & 0.4 & 0.6 & 0.6 \\
$7-9$ & 0.9 & 0.9 & 0.3 & 0.6 & 1.2 & 1.5 \\
$10-14$ & 2.0 & 1.6 & 0.4 & 1.3 & 2.4 & 3.2 \\
$15-19$ & 5.0 & 4.1 & 0.3 & 2.0 & 5.3 & 6.1 \\
\hline
\end{tabular}

Sources:
a. Cain (1977), Table 4.
b. Nag, White, and Peet (1977), Tables 3 and 4.
c. Nag, White, and Peet (1977), Tables 1 and 2.
d. De Tray (1983), Table 2, Panel for Malays. 
over the 15-year period, mainly due to the mechanization of post-harvest operations, which were traditionally carried out by women. This decline may provide an incentive for women to migrate to urban areas in search of work. Table 2 shows that young married women work longer hours on average, because after marriage they assume the role of wife and mother; and, in those villages where households were typically formed not long after marriage through couples leaving the husband's extended family to set up their own household, it also entailed full adult responsibilities in other ways (Amin, forthcoming). Marital status appeared not to make as much of a difference for boys as it did for girls.

Time-use studies conducted in several countries in Asia found few differences between socioeconomic groups in the length of the workday. Cain (1977), analyzing differences by landholding, found some difference in the nature of work performed, with children from poor households being more likely to engage in wage work. Similarly, De Tray (1983) reports that, in Malaysia, family economic conditions do not predict whether children participate in economic activity, but differentiation exists in the nature of work

Table 2 Women's mean daily hours worked by age and marital status, Rajshahi, 1991-92

\begin{tabular}{lcccccccccc}
\hline & \multicolumn{2}{c}{ Income earning } & & \multicolumn{3}{c}{ Home production } & & \multicolumn{2}{c}{ Total } \\
\cline { 2 - 3 } Age group & Married & Single & & Married & Single & & Married & Single \\
\hline $10-14$ & 0.62 & $(30)$ & $1.33(767)$ & & 4.01 & $(30)$ & $1.60(767)$ & & 4.63 & 2.93 \\
$15-19$ & 0.86 & $(258)$ & $0.98(264)$ & & 5.07 & $(258)$ & $3.19(264)$ & & 5.93 & 4.17 \\
$20-39$ & $1.17(1633)$ & $1.55(153)$ & & $6.86(1633)$ & $4.64(153)$ & 8.03 & 6.19 \\
\hline
\end{tabular}

Number of women is given in parentheses.

Source: Tabulated from time use data described in Amin (1996). 
by social class. De Tray also showed that, at least while still at home, girls contributed more to the household economy than boys since they engaged in about equal amounts of household labor as boys, while also being engaged in housework. White (1994) reports on change over time in the pattern of work for children and young adults. In 1976, children's work in his Javanese villages consisted of peasant agricultural activities such as animal care, crop cultivation, and handicraft production as well as household work. In time the nature of and motivation for work have changed as more opportunities have become available in Java's growing economy, but the fact of engaging in substantial hours of activity has remained true for both girls and boys. In settings at the early stages of mass education, such as Indonesia in the 1970s (White, 1994) or Bangladesh in the 1990s (Amin, 1996), schooling appears not to preclude substantial work by children and adolescents, particularly when they belong to subsistence or household economic enterprises. The data suggest that a low average number of hours spent in school allows children to continue to work while they attend school.

\section{Economic activity}

A comparison of International Labour Office statistics, despite their acknowledged flaws, reveals that as societies develop they typically experience an increase in female labor force participation in the formal sector and that the age-specific patterns become closer to those of men. Increased participation of women in the formal sector is often attributed to the globalization of production in such sectors as garment manufacturing and electronics. While we do not explore the motivations for globalization, one strand of writing is relevant: it argues that while globalization of manufacturing has 
led to increased numbers of women entering the formal sector, this has occurred only because young women are willing to work under the exploitative terms on offer (Standing, 1989). Young women workers are preferred because they are flexible and more willing to work at below family wages and under conditions that men would not consider acceptable (UN, 1995a; Standing, 1989).

\section{Labor legislation}

Another way of reducing labor costs is to engage underage workers. Manufacturers are motivated to locate in less developed countries where child labor laws are not enforced. There is evidence that workers in Bangladesh enter garment factories at very young ages, often in their early teens. Countries with weak enforcement of child labor laws have a comparative advantage over settings where the laws are enforced.

Concerns about such exploitative working conditions have resulted in legislation in more developed countries that aims to encourage stricter implementation of labor laws in less developed countries. Most recently, the Harkin Bill, introduced in the US Congress, argues for sanctions against producers employing child labor in factories overseas. Consumer groups have also advocated boycotts of products retailed in the US that are produced by child labor overseas (Basu, 1994). Although the popular image of child labor is of children who are well below the age of puberty, labor legislation has typically also included young adolescents, particularly those aged 11-13 years. With respect to garment work the focus of labor legislation is often on young women of these ages.

As a result of concerns in the West, countries like Bangladesh have increasingly enforced child labor legislation. Although these laws have al- 
tered hiring practices in factories (Bhattacharya, 1996) they have not markedly impeded the development of the garment sector, which continues to grow at unprecedented rates. It is also unclear whether child labor legislation has any overall effect on children's work since those who are not working in factories can still find employment in the informal sector.

White (1994), reviewing labor laws in Indonesia and the Netherlands, has argued that child labor activism is essentially misguided in trying to ban employment of children. He argues that what is objectionable about child labor is not necessarily the fact of their working in factories but the conditions of work: hazardous environments, long hours, low wages. These conditions would be better addressed by regulating and legalizing the conditions under which children can work for cash, rather than by simply attempting to introduce legislation to ban child labor. White's principal observation is that children want to work for cash (rather than perform unpaid family work, which is deemed more acceptable in the West), and making child labor illegal only makes it less visible.

In a setting such as Bangladesh where girls are considered eligible for marriage soon after puberty, and work provides an alternative to early marriage, child labor legislation could have potentially important consequences for reproductive health. Parents who are not able to send a marriageable daughter to work may be motivated to opt for early marriage. We next seek to bring a new perspective to the debate on children's work and the related topic of entry into work for adolescents.

\section{A STUDY OF BANGLADESHI GARMENT WORKERS}

The empirical work in this paper is based on case studies and a social survey of garment workers living in Dhaka, Bangladesh collected as part of 
a larger ongoing study of garment workers in the country. Interviews for the case studies were conducted between July and December 1996. Respondents were selected from factories of varying size located in four areas of the city. Workers were selected on the basis of marital status and type of occupation to ensure that the detailed case studies would reflect the range of experience of workers in the garment industry. Twenty-two workers served as focal cases. Interviews were semi-structured and open ended, with a focus on the decision to work and associated changes in all aspects of life with particular regard to marriage and family relations. Interviews were conducted during repeated home visits taking place over the course of as much as a month. Such a strategy was followed so as to verify and cross-check initial accounts on the basis of repeated narratives and different perspectives. Developments over the course of the interviews provided important insights into the biographical narratives.

The second source of data is a social survey carried out between February and April 1997. This survey covered both garment workers and other workers. A systematic sample of 301 helpers and operators and 50 supervisors were interviewed from 13 randomly selected garment factories. The ratio of helpers and operators in the sample matched that found in each factory. All female supervisors were interviewed for separate detailed analysis as a select group of highly successful workers. ${ }^{1}$ An additional 705 helpers and operators were contacted by a snowball sample from the factory-based sample. A total of 513 non-garment workers were also interviewed as a control group selected to match the worker sample by age and socioeconomic status. The control group came from communities that have sent a high concentration of workers as well as from communities that are not characterized by high migration for garment work (referred to in Tables 5 and 6 as sending 
and non-sending areas, respectively). The structured questionnaire covered topics similar to those found in the qualitative interviews: family background, current living arrangements, work and migration history, income and household economy, marriage and childbearing histories, and aspirations, contraceptive use, and health.

A summary of six of the case histories of garment workers is shown in Table 3. These summaries provide a reference point for those cases that are frequently referred to in the text and that illustrate the lives of adolescent workers. The summaries provide a glimpse of the life cycle of garment workers and how entry into garment work, promotion within the industry, and movement between factories fits into changing family circumstances and living arrangements. All six women entered garment work by the age of 16 years and, in some cases, such as Shakti, at considerably younger ages.

In terms of age, marital status, and migration, garment workers are similar to rural migrants elsewhere in Asia: young women move to the cities for work when they are very young and single, using networks of family and friends to help them enter factory work (Findley and Williams, 1991). The initial months of the transition into employment, which includes migration to the city and perhaps finding housing and a job, require considerable wherewithal and the support of a network of family or friends who are familiar with the relevant settings. Workers can leave this dependent stage very quickly because, within a year, they can expect to earn substantially higher salaries by working long hours to earn overtime, being promoted from helper to operator, or moving to a new factory. However, there is considerable variation in the extent to which workers choose to take advantage of this independence. They opt to live with their family or relatives when possible, pool resources, and save money; and most fulfill important filial roles by pooling their income. 


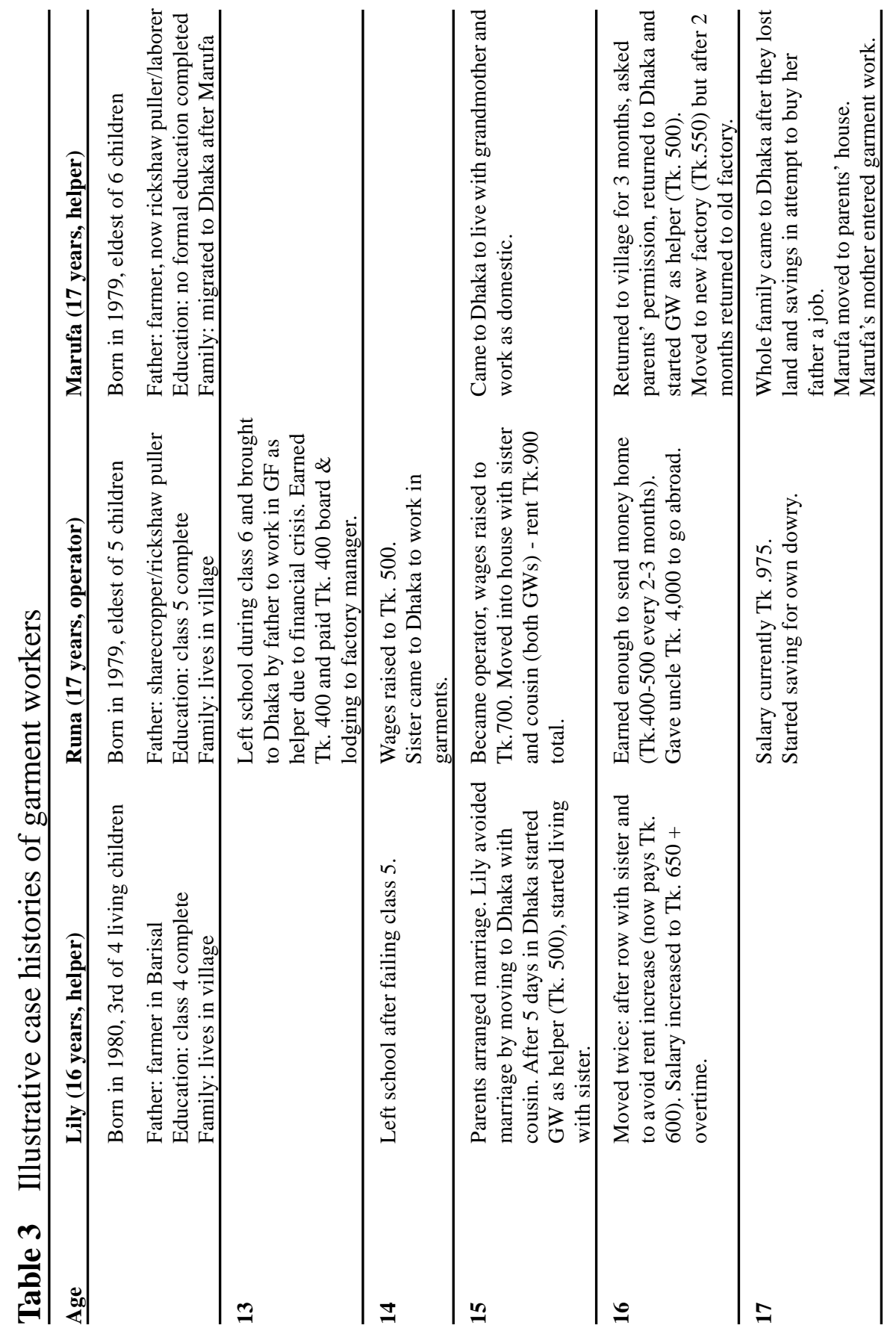




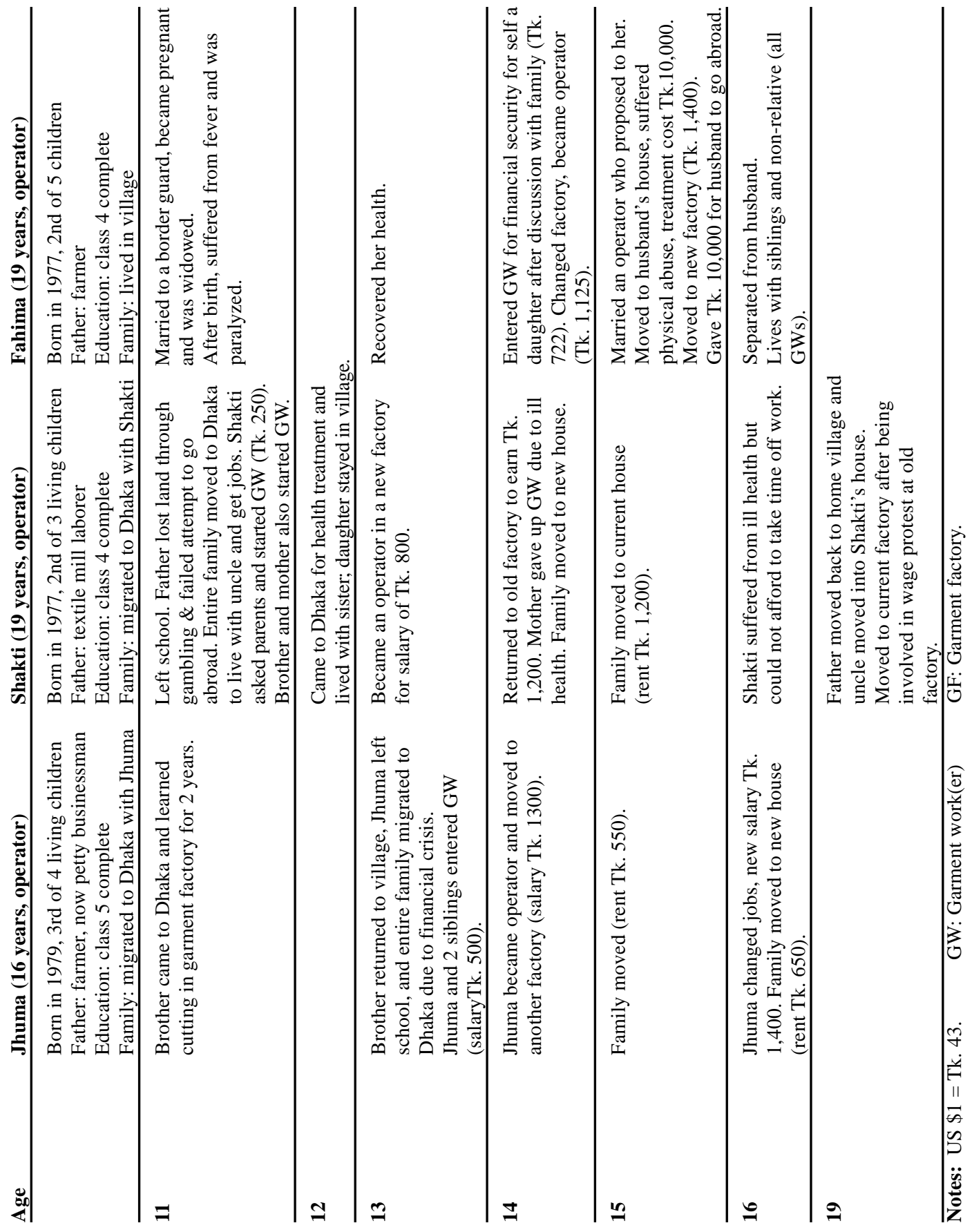


In the early years of the garment industry, considerable stigma was attached to garment work; this still exists but to a lesser extent. Despite this, there is strong evidence from the narratives of these young women that the opportunity for employment is generally thought of as a positive development. Factory work is considered to be modern, and therefore superior to agricultural work, despite the long hours. The combination of delayed marriage and the small luxuries that increased incomes allow creates a positive period of transition into adulthood. Defining adolescence broadly as a period of transition when a person is no longer a child yet not a social adult, when many social and psychological characteristics are in the process of being defined, and when considerable effort is invested in preparation for adult roles, we argue that the experience of work in the social context of Bangladesh has all the elements of adolescence thus defined. Furthermore, for a large proportion of young Bangladeshi women, garment work has brought this opportunity for the first time.

The discussion of case studies and survey results is organized under the following headings: factors that affect the decision to enter garment work, the way in which workers initially experience entry into the workforce, issues related to management of income, workers' own evaluation of their status and the reaction of the society around them, workers' socialization into the new environment of work, garment workers' transition to adulthood, and the implications of garment work for reproductive health.

\section{Reasons for entry into the garment industry}

While there is variation in the reasons for entry into work, most workers do so at young ages before they are married. The quantitative survey 
shows that 47 percent of respondents entered garment work below the age of 15 years and 32 percent between ages 15 and 19. Overall, 69 percent of respondents were unmarried and under the age of 20 when they entered work. The majority are migrants: 87 percent of respondents were born in rural Bangladesh. Some may have migrated to Dhaka earlier in their childhood, but a significant proportion move in association with entry into garment work. Entry into garment work is often triggered by an immediate need to improve or stabilize the household's finances. But, as will be seen in a later section, the woman's income contributes to a large range of household needs, and she continues in garment work even after the need that triggered entry into employment has been met.

Even after workers gain the potential for economic autonomy through work, familial and social networks continue to assert a considerable influence on their lives. All women highlighted in Table 3 entered garment work in the context of family support. Where the respondent migrated without her parents, she initially relied on a female relative for help in Dhaka (Lily and Marufa) or on a personal contact with the factory production manager through her father (Runa). Even Lily, who migrated to Dhaka without her parents' consent, was supported (emotionally and practically) by her sister and cousin, and a few days after her arrival in Dhaka her father sent her some money to assist her. Women who migrated with their parents or the whole family initially stayed with an uncle (Shakti) or relied on the experience of a sibling who had previously migrated to Dhaka (Jhuma). The family support networks continued even after the respondents had become established in Dhaka, and the workers themselves were followed to Dhaka by and offered support to sisters, cousins, and even their whole family (Runa, Fahima, and Marufa). 
Since the decision to enter work is often part of a household strategy, we examine the narratives of parents and guardians as well as those of the workers themselves. The following narratives illustrate the diversity in motivations.

Grandmother of Runa (see Table 3) and Selima, daughters of a village rickshaw puller: "The production manager of the factory was a school friend of their father. He heard that the rickshaw puller had four daughters to bring up and suggested the idea of sending the eldest daughters, Runa and Selima, to work in Dhaka. Runa came first and lived with him and he got her a job as a helper in his factory."

Halima Begum, 45, mother of three garment workers, two daughters (including Jhuma, Table 3) and one son: "We moved to Dhaka after the 1988 floods when my husband lost all his money in his rice trading business. My husband got sick and went back to the village six months after we first came, but I stayed behind with my daughters and sons who are all working in the city now."

Monira Begum, 40, mother of Padma, 19, a married operator: " $M y$ husband had TB and the doctor said he could not work for three years at least. It became difficult to manage his treatment, groceries, and the rent on my income alone. Other girls go to work in the factories to help out their families, so my husband and I suggested to Padma that she should quit school after Class V and go to work."

For workers who report that their decision to enter employment was made by their parents, it is uncommon for either workers or their families to report that the decision was imposed. Runa, now age 17, was sent to Dhaka 
by her family to enter garment work when she was 13 or14 years old (see Table 3). She describes how she reconciled herself to the family's decision during the difficult initial days of coming to work: "I would cry all the time when I first came to work, but I told myself, my father is poor and he has five children to feed. He has to send them to school . . . so I convinced myself to stay."

Most workers who, like Runa, are the first in the family to enter garment work are motivated to search for work in response to a crisis. Their narratives suggest higher levels of stress at the beginning of garment work than experienced by later arriving siblings, who may have more information and easier transitions and thus tend to give a more positive portrayal of their entry into work. Runa and Selima came from a village about two hours from Dhaka to enter the same factory where their father's childhood friend worked as production manager and found them jobs. Although it was the parents' decision that the younger sister, Selima, should also go to work, the two sisters describe their experience very differently. Runa describes being sad and traumatized initially, while Selima says she took her time to decide about entering garment work. She says she did not initially agree to go to work, but then a visit with Runa made her realize that Runa and her working friends had a good life, so she decided to join them.

Similarly, two other sisters, Shakti (Table 3) and Shireen, came to the city with their parents and both started working in factories at around age 11. Shakti's younger sister, Shireen, was taken to the garment factory where they worked by her mother and brother due to a lack of alternatives for child care. As she became older Shireen began to help with various tasks until she was deemed to be sufficiently productive and started to draw her own wage. Thus in contrast to the experience of Shakti, whose entry into garment work, 
shortly after the family's arrival in Dhaka, meant a clear break with her previous life, for Shireen entry into garment work was a gradual process. In all six cases in Table 3 the respondent is not the only family member to work in the garment industry. In some cases the whole family migrated to Dhaka and several family members entered garment work at the same time (Jhuma). In others the respondent's parents remain in the village but several siblings and cousins work in the industry, having entered at different times and assisted each other in obtaining jobs (Lily, Runa's sister and cousin, Fahima's sister and brother). In two cases the respondent's mother has also worked in the industry at the same time as the respondent (Marufa, Shakti); where dictated by financial necessity, married women also join the garment industry.

Thus, as Kibria (1996) has argued, entry into work is made easier when familiarity with the support structure facilitates migration, helps in locating a job, and provides some level of subsidy for subsistence in the initial years. When family members already live in the city, the transition is relatively smooth. In general, social networks through school, contacts in the village, or kin relations through marriage facilitate the process. As a remark from a member of the Garment Manufacturers Association shows, factories rely on these networks as well:

"Garment working women come from villages and slums. Women move from villages to the slums and their contacts in the slums help them obtain employment in the garment sector." 2

There is little evidence of more formal ways of locating workers, although posters and newspaper advertisements are sometimes used. Instead, it is common for factory managers to spread the news of a need for workers by 
word of mouth. At best, notices are posted at the factory door for current workers to note and pass on the information among their neighbors and friends.

Although much less common, a number of reports of events leading to entry into work relate to individual rather than household-level decisionmaking. One of the women in Table 3 (Lily, a 16-year-old single helper) illustrates an unusual instance of rebellion. She ignored the wishes of her family and left the village to find factory work in the city in order to avoid being forced into a marriage she did not want:

"I knew my father wanted to marry me off so I went to my cousin who was a garment worker in Dhaka and had come home for a holiday and told her I wanted to go with her to Dhaka."

Two other women also referred to personal decisions about entering garment work. Marufa (Table 3) was sent to Dhaka by her parents to live with her grandmother and work as a domestic servant. After less than a year she returned to her village and requested her parents' permission to enter garment work. Despite considerable opposition from her parents Marufa did enter garment work; subsequently her family followed her to live in Dhaka and are now heavily dependent on her income. Shabnaz, who later dropped out of garment work after marriage, came to Dhaka to live with her aunt and attend school. However, her aunt did not enroll her in school and she was in effect working as a domestic servant for her aunt. After several years she asked her aunt and father to allow her to work in a garment factory. Thus for some women entry into garment work is a personal decision, sometimes with family permission, made because it is seen as a positive alternative to domestic work or early marriage. 


\section{Initial experience of work}

For many women the initial experiences of work were not good. The young women describe fear and confusion about finding their way around the city and difficulties adjusting to supervision in the factory. In the process, however, the women gain important negotiating and managing skills.

Nasreen, 14, single helper: "On the first day I lost my way coming home from work. My older sister found me standing by the road, crying, and brought me home."

Runa, 19, single operator living away from home: "I hated walking to work - the rickshaws, cars, and crowds on the streets scared me and I didn't even know the way to the bazaar."

Shabnaz, 19, currently an unemployed helper: "Work in a garment factory is no joy ride. They set a target of 120 pieces for you for the day, but it is not possible to do more than 80 pieces, so they make you work 2-3 hours of overtime. But then when you go to get your time card signed it shows worked till 4:30 (regular hours)."

Given that there are many new and unfamiliar settings to negotiate after finding a factory job, it is not surprising that workers choose to live with family and relatives if they can. Thus, in addition to providing functional support as sources of access and information, families must also play an important psychological role. In our quantitative study, 87 percent of respondents aged 10-14 and 81 percent of those aged 15-19 lived with parents, spouses, or other relatives. 
It is clear that most workers are recruited only after they pass a number of skill tests to demonstrate some familiarity with the English alphabet and numbers as well as practical ability for garment work. These skills are needed for promotion to the position of operator.

Marufa, helper: "There are numbers in English, I cannot read those numbers. If I could read those I could become an operator. If you become an operator your status will be different."

These tests, which are trivial for anyone with a basic education, may encourage parents to ensure that their daughters have some education. However, results from the quantitative survey show that 48 percent of adolescent workers (47 percent of 10-14-year-olds and 44 percent of 15-19-year-olds) have no formal education. Thus, while there are clear advantages for those who have some education, the factories do provide work opportunities to intelligent women without formal education. Workers are subject to a test at the time they are recruited. Lily, a 16-year-old single helper (Table 3), describes her own experience:

"Five days after coming to Dhaka with my cousin, we got a neighboring factory worker to take us to the factory and she introduced us to the supervisor. First, the supervisor told me to match two numbers, then she asked me to cut a piece of thread with the cutter. We (me and my sister) started working that day and she asked us to bring in an application with a photograph which we submitted five days later."

Lily describes her experience simply, but the process can be quite complicated. She must have had to go to several workers to find a factory that 
was recruiting at the time; she was relying on the generosity of her cousins to support her so she was in a rush to find a job; and it must also be difficult for a young village girl to find a place to get photographed and to fill out an application form.

\section{Managing income}

Since the primary motivation for entering work is to earn a living, salary histories are an important part of the workers' narratives. Their view of the prospects for economic mobility, management of income, propensity to save, and patterns of expenditure provide insights into the lives of the workers. Most garment factories have several categories of workers: entrylevel workers are called helpers or apprentices; helpers capable of reading the English alphabet and numerals graduate to operators, at which point they learn to run machines; rarely, some workers with secondary education may graduate to the role of line chiefs or supervisors. Although the ratio of helpers to operators varies, in a typical factory it is about one helper to two operators but the number of senior posts is very limited. For example, a factory of 300 workers will have fewer than ten supervisory posts. Nevertheless, since some supervisors start as helpers it is not uncommon for a helper to aspire to become a supervisor. Salary and incentive structures are similar across factories. In the quantitative survey the mean basic monthly wage of helpers was Tk. 625 and that of operators was Tk. 1307. We found that 33 percent of workers did not receive any overtime; however, that figure may reflect irregularity in payment of overtime rather than the percentage not working overtime. Among those who do receive overtime earnings, the mean for helpers is Tk. 223 and for operators Tk. 407. ${ }^{3}$ 
Within an occupational category, variation in wages can be substantial, depending on seniority and performance. Most workers describe relatively rapid wage increases in the first year of work. Several young women expressed this prospect of mobility as an important positive aspect of their work experience, and one that is not characteristic of other potential work opportunities. Examples of occupational mobility of workers can be seen in Table 3. Most women in our study who have worked in the garment industry for more than a year have changed factories at least once and have been promoted from helper to operator. Shakti changed factories several times and her wages quadrupled, even though part of the apparent increase may reflect wage inflation over time. The cross-sectional survey data in Table 4 show that although basic salary increases with duration of employment, the change is more modest than what is suggested in retrospective reports-

Table 4 Mean total income of garment workers, in Taka, by occupation and duration of employment

\begin{tabular}{lccc}
\hline Duration (years) & Helpers & Operators & All workers \\
\hline$<1$ & 741 & $1,247^{*}$ & 836 \\
$1-<2$ & 773 & 1,327 & 1,043 \\
$2-<3$ & $881^{*}$ & 1,505 & 1,267 \\
$3-<4$ & $830^{*}$ & 1,509 & 1,434 \\
$4-<5$ & $1,011^{*}$ & 1,540 & 1,518 \\
$5+$ & $1,078^{*}$ & 1,745 & 1,720 \\
\hline
\end{tabular}

Notes:

Data weighted by occupation, place of residence, and age. Only helpers and operators are included.

Total income includes monthly basic wage and overtime.

US $\$ 1=$ Tk. 43

* Indicates sample size of fewer than 50 cases. 
workers who have been in the industry for five or more years earn, on average, twice the wage of new entrants. By looking at wages by employment duration for helpers and operators separately, we see that part of the wage increase is due to promotion to operator but that within an occupational category there is scope for wage increases.

Shakti's sister Shireen, a 17-year-old operator, describes her experience of wage promotion and strategic moves between factories to improve her wages:

"When I started work the factory offered me a monthly wage of Tk. 250. Twenty days later I went to another factory where they offered me Tk. 800. Nine months later, I went to a third factory where I got Tk. 1,200. I stayed there for three or four years but my wage increased only by Tk. 100 and they did not always pay at the same time of the month. So I came to this factory and I now make a total of Tk. 1,600 in wages, transport expenses, and bonus."

Movement between factories is related not only to wage level but also to regularity of payment, amount of overtime work, personal relationships with management, and attitudes of families. Thus Runa's lack of mobility between factories (see Table 3) may be attributed to a family relationship with the factory production manager, and Fahima moved to a new factory after marriage (see Table 3) because her husband preferred that she work in a factory where there was less interaction between male and female workers.

The workers' narratives describe the low level of entry-level salaries that are often inadequate to cover even subsistence. Runa (see Table 3) describes her financial situation when she first began garment work: "I made 
barely enough money to pay for rent and food. I earned Tk. 500 but my rent and food came to Tk. 400."

Garment workers learn quickly that by working hard and negotiating with management, they can increase their income rapidly. Changing jobs and moving to a new workplace may be an integral aspect of earning better rates. Better-educated workers also start at the apprentice level but may make faster progress through the levels. Although Aleya is earning more than her roommate Runa, who has slightly higher education, she, like other garment workers, has indicated how education comes to be valued because it is rewarded with faster progress in the factory:

Aleya, a 20-year-old single operator: "I stopped studying after Class $V$ because my father was religious and did not believe in girls' education. Now I know the value of education. No one can take it away from you, it is your very own. If my father had let me, I would have been a doctor. ... If you have more education you earn more...you are more likely to become a supervisor if you are a Matriculate."

In terms of expenditure patterns, workers maintain the near subsistence level of expenses on food and rent that they had at the start of their work life and try to minimize unnecessary expenditure. Parul, a single 23year-old operator with considerable savings, describes how she manages her spending:

"I hand over my wages to my mother and take a small allowance from her everyday. I don't go to the movies - - I save the money. I also save money by walking rather than taking a rickshaw. I sew my own clothes." 
It is common for girls who are still living with family members to hand over their entire earnings to the head of the household and to expect to receive an allowance for travel to work and incidental expenses, in the way Parul describes for herself. Others hand over their basic salary and keep their overtime earnings for personal expenses, allowing women to manage their own income. Data from the quantitative survey show that 42 percent of workers pool all their income in the household, 43 percent pool some in the household, and only 15 percent keep their whole income. Among adolescents, 77 percent of 10-14-year-olds pool all their income, compared with 48 percent of 15-19-year-olds. Thus it seems that the scope for some control over income rises with age and income.

Workers are expected to contribute toward household expenses regardless of whether they live at home or independently, and most oblige. Among the respondents who lived with their parents, or with an older sibling as household head, most did not retain control over their income. However, this rather unvaried reporting may be more a reflection of the image of a dutiful daughter that the women want to portray. As one grandmother of two workers says:

"My granddaughters are good girls and they send money home to their father every month. They are not like those other garment workers who are always spending their money on clothes and movies."

Regardless of how much control they retain over their income or their savings, workers know the extent of their own savings and can report what they have accumulated even when these savings are controlled by other family members or are pooled in the household savings. Parul, for example, has 
saved Tk. 20,000 after five years of work. She has unusually high savings because in her initial years of work she was supported by her sister's husband. When the sister was divorced, Parul and her sister started pooling their income to run the household, but Parul's savings remained intact. Parul said:

"I cannot spend my money as I wish...my mother says, 'by saving money I will arrange your marriage into a good family'... Dowry will be needed for my marriage, not much, Tk. 10,000. The groom's family will give earrings, bangles, and necklaces. My Tk. 10,000 is deposited in the bank."

During this period of adolescence, garment workers are acquiring adult skills such as management of their budgets even though they may not retain control over most of their income. As income levels increase so does the proportion of the salary that is saved by the worker herself or remitted to her household of origin, barring major events such as marriage or changes in household circumstances.

Workers living away from their family may retain greater control over their income, but the custom of remitting, thereby increasing resources for the education of siblings or the sustenance of the family, appears to endure. Runa, 17 (Table 3), now earns Tk. 975 per month, of which Tk. 500 goes for food and rent. She is not able to remit money to her family each month but she buys clothes for them and tries to give her father Tk. 400-500 (from her and her sister's earnings) when he visits her every two or three months. In addition, Runa manages the accounts for her younger sister, who also works in the factory, lives with Runa, and hands over all her wages to her. After about four years of spending most of her surplus on her family, Runa and her 
family decided that she should stop sending money to the village and start saving for her own dowry, because as Runa says:

"Money has to be paidfor marriage. I don't know how much will be needed. If you can give a larger amount of money you can get a better groom."

When earnings are sufficient, the propensity to save is strong among all garment workers regardless of the extent to which they manage their own savings. The form of savings varies widely - it can be placed in a bank account, with a rotating savings group at the factory, lent out for interest to friends, family, or co-workers, or converted into gold jewelry to serve as a dowry.

The most striking feature of the workers' management of their income is that even after they have demonstrated considerable ability in the workplace by earning high wages and negotiating better working conditions, retaining autonomous control over the income earned is not a common concern. Instead, most workers believe that their incomes are integral parts of a larger household budget regardless of whether the worker lives at home or elsewhere. While the narratives reveal that workers are keenly aware of ways to increase their wages, they remain submissive with regard to decisions in the household. Part of the explanation must lie in the fact that they perceive serving their household's interests as being in their own long-term interest. As Kabeer (1991) argues, there may also be pressure to conform to traditional patterns of female behavior, which includes submission to household interests as dutiful wives and daughters, to compensate for generally negative perceptions about garment working in the society at large. These perceptions are described in the next section. 


\section{Social costs and benefits for garment workers}

Several researchers have noted the considerable social stigma attached to garment work in Bangladesh (Kibria, 1996; Paul-Majumdar and Zohir, 1994). Awareness of this stigma is apparent in the workers' accounts as well as in the narratives of those around them. In the early years of the development of this sector, garment working may simply have been stigmatized as deviant behavior. Over time the workforce has expanded rapidly and the nature of the stigma has changed. With over one million women engaged in such work, working in the garment industry can no longer qualify as deviant or unusual behavior. Some of the respondents noted that even during the time they have been working in the industry, they have observed an improvement in attitudes toward garment workers.

The quotes below show how workers and their families perceive the societal attitudes and adapt to them:

"In our country those who do not work are regarded as good girls. If a girl works, people ask many questions - where is the office, what is the office like, what is the work? But it is not worthwhile to give importance to these words. One cannot sit idle just to be called a good girl. One has to do something and stand on one's own feet." (Shanti, 21year-old single supervisor)

"We do not go to visit my husband's brother because they are rich and educated and they feel uncomfortable about acknowledging our relationship." (Mother of three single garment workers; see Jhuma, Table 3) 
"My marriage has been arranged to a private car driver but he has not been told I work in a factory - he thinks I work for a tailoring shop like my sister.. . I have my reputation to keep, people do not respect those who work in the garment factory." (Parul, 23-year-old operator)

"Our neighbors and relatives do not look well upon garment work. Landlords don't want to rent to us. Proposals come for girls, but then they back out when they find out she works in a garment factory." (19year-old worker)

Workers and families often justify the decision to work as a strategy for saving for their own dowry or marriage expenses, although often it is not paid. Dowry is mentioned as a motivation for sending daughters to work, perhaps in order to overcome the stigma attached to the inability of male members to support the family. Workers themselves mention dowry as their motivation for saving.

Garment workers are also stigmatized for their greater autonomy and mobility. They are assumed to be at risk of sexual activity outside marriage since they spend extended parts of the day beyond the supervision of their family. In discussing the social stigma associated with their work status, the respondents reflected on their strategy for coping with both elements of the stigma. Workers address their compromised situation with regard to marriage by saving and paying for their own dowry. On the matter of risk of sexual activity, they portray the workplace as a protected environment. The social construction of the workplace is an important element in how young working girls reinterpret values of seclusion or purdah in light of their changing work status (Siddiqi, 1991), described in more detail in the following 
section. Workers are most likely to associate with other garment workers when interacting outside the family network. Garment work necessitates frequent movements between the protected spaces of the home and the factory. Many workers attempt to protect themselves from negative judgments in the public space of the streets by covering their head and upper body with a large scarf and ignoring men who accost them. They are also likely to cope with the discomfort of the negative images by thinking of garment work as a transitional phase.

"The garment boys also ask me to marry them but I do not agree. If I marry a garment worker I will have to work in the garments for my whole life. So I don't want to marry a garment worker. They get such a low salary.” (Runa; see Table 3)

Kibria (1996) argues that work for young women is not yet "normalized" - wage work before marriage as a stage of life for women has not yet become the norm, as is the case in most East Asian countries. For this to be a normal life-stage, there needs to be greater social acceptance of garment work than is evident at present, even though the women themselves value the modern nature of their work, consider garment work to be of lesser hardship than most forms of agricultural labor, and value the autonomy and independence that come with the income.

The stress of garment work is not often spoken about directly but, instead, is reflected in the concerns workers express about their health. These concerns range from losing weight and looking tired and overworked to actual complaints about eyesight or illness. The quantitative data show that in the month before they were surveyed 73 percent of respondents suffered 
from head and ear complaints, 69 percent from general fatigue, and 45 percent from eye problems. Approximately a third of those who suffered from head and ear problems during the preceding month sought treatment. Basu (1992) describes similar concerns about health and frequent visits to doctors and pharmacies in her study of urban slum dwellers in Delhi. Our case studies provide some detail on the type of treatment sought. For minor complaints, respondents usually go to the pharmacy and buy medicines recommended by the shopkeeper. For more severe symptoms they usually visit a private physician. The narratives give the impression that the frequency of visits to the pharmacy or doctor is considerable, and several respondents mentioned major episodes of illness that have accounted for large expenditures of their income.

On the other hand, the workers' narratives reveal that, despite a general awareness of the costs of work in terms of stigma and physical stress and the need for strategies for coping, at a personal level these are offset by enhanced confidence in their own abilities. These evolve as workers demonstrate their abilities at work, by demanding and receiving wage increases as they fulfill performance requirements. Workers also indicated that the technological nature of their work and the inability to operate sophisticated machines are an important part of their self-image, as is the higher quality of life they can now afford as a result of the move to the city and better incomeearning opportunities. In describing how garment work has changed their lives, workers typically listed positive feelings about earning an income and being able to help the family, living in the city with indoor toilets and running water, and being able to afford to go to the doctor.

Workers appear to maintain a higher standard of dress than their nonworking sisters, adhering to the latest fashions and spending money on make- 
up and jewelry. Since there are few role models for young working women and they clearly do not fit any traditional cultural mold, workers also have the opportunity of defining new roles for themselves. The quote below by Padma also suggests that by dressing smartly and living well, garment workers attempt to reduce some of the social costs of their employment:

"The garment girls live a posh life. They wear good clothes and expensive clothes. They even wear sandals worth Tk. 300. Because people neglect garment girls and do not respect them, that is why they live a posh life, so that people will value them." (Padma, 17-year-old married worker)

The narratives suggest that workers see themselves as being in an intermediate stage between childhood and adulthood. The clearest outward manifestation of this is their manner of dress - most workers wear a form of clothing called shalwar kameez, which is considered too grown up for children and too young for adult women but is deemed appropriate for garment workers. Rural women, on the other hand, typically make a direct transition from dresses and shorts as girls to wearing the sari, which is the preferred adult garment. The shalwar kameez is a northwest Indian costume that has come into vogue in Bangladesh only since the 1960s. So, in addition to being intermediate between child and adult, it is also associated with being modern or trendy. In contrasting her lifestyle to that of her friends in the village of similar age, a worker says:

"My married friends have to wear sari but I can wear shalwar kameez. They cannot go out of the house on their own and I go back and forth between the village and the city; they are not as confident or brave as 
I am. I have learnt a new trade and have a job, they sit in the corner of the house and cook all day.” (Aleya, 20-year-old single operator)

There is ample indication that garment workers are consciously "modern" and "smart" and keen to project such images. The titles that workers are given are expressed in English, which helps to formalize their designations helpers (sometimes apprentice), operators, supervisors, cutters. These categories are organized in a hierarchical manner with differentiated pay scales and skill requirements. A girl starting out can quickly set concrete goals for advancement. Factory workers' need to maintain daily and monthly time cards at work probably serves to ascribe value to their time.

Migrant workers are able to reinforce this modern image further by changing their dialect and affecting urban accents.

Fahima, 19-year-old operator, married twice and now separated (see Table 3): "When I go back to the village they are impressed by my nice clothes and my nice (city) accent and people like to come to hear about my experience and I get a lot of attention."

One feature of adolescence that is identified in the literature (e.g. Aziz and Maloney, 1985) is the creation of peer groups in which young people, by interaction and group identity, can develop a personal identity. Traditionally in Bangladesh, when women moved quickly from being someone's daughter to being someone's wife and someone's mother, many lacked the opportunity to develop their own identity (Aziz and Maloney, 1985). Even in urban Bangladesh, however, where significant changes are taking place in the lives of young women, social norms make it difficult to discuss sexual activ- 
ity among the unmarried. We were able to gain some insight into young women's socialization through discussions on seclusion and the maintenance of purdah, which is perceived to be centrally concerned with women's sexuality.

\section{Socialization and social interaction}

The tradition of purdah is perceived as a set of rules to control sexuality by minimizing interactions between persons of the opposite sex. As mentioned previously, on the streets workers usually wear a scarf over their head and body to avoid being seen by men. Most workers interpret purdah as avoiding contact with men and wearing clothing to hide face and form. However, these scarves are cumbersome and hamper efficiency so they are not worn on the factory floor and sometimes are even explicitly forbidden by management. Nor is it possible to avoid male contact on the factory floor. For these reasons, most workers concluded that their lifestyles do not allow them to adhere to the strictures of purdah. Some choose to reinterpret purdah in the manner described by Simmons, Mita, and Koenig (1992) for the first generation of family planning workers, as a state of mind rather than a physical manifestation; others prefer a looser interpretation of physical behavior such as "purdah is avoiding physical contact with a man."

Workers also cope in other ways with their inability to maintain purdah. As Siddiqi (1991) suggests, common strategies for maintaining purdah include portraying the factory as "indoor" space and perceiving the factory supervisors and managers as "elders" whose role is to regulate the morality of workers. More articulate or liberated women tend to redefine purdah as a state of mind, but curiously no one questions the basic morality of purdah itself, just the practice. 
In a manner similar to discussions about sexuality with adolescents of South Asian origin in Great Britain (Hennink, 1997), comments made by workers suggest some level of sexual activity among their peers even though they would never discuss their personal experiences:

"I heard that someone did it (had sex) in the factory between the machines."

"Girls flirt and brush up against men when they are working together and they joke and laugh with them."

These are some of the elements in the accounts of garment workers that portray them as being similar to adolescents in the West. A significant difference from the West, however, is that none of this activity is socially approved or accepted, and the sanctions against such interactions with men remain strong. So, for instance, one of our male respondents described how his marriage was precipitated by the fact that he had an "open" date with his future wife:

Masum, a 24-year-old male worker married to a coworker: "Iforced her to go to the movies. The next day everyone at the factory came to know about our date. I had a row with her sisters on the factory floor who said they would never choose a person like me for their sister to marry."

Masum was embarrassed by this confrontation and swore he would not show his face in the factory again without marrying the girl. He married her that same evening in the marriage registrar's office. 
There is evidence among garment workers of changes in the ways of controlling exposure to sexual activity through the rigid rules of physical behavior. Siddiqi (1991) argues that since the essential values of seclusion are maintained in the reinterpretations, the institution remains intact. It could also be argued that the fact of reinterpretation and the recognition of the need for greater freedom of movement mean that norms are changing in a consequential manner. Under either interpretation, the context in which sexuality is managed is changing, probably with a somewhat greater possibility of premarital sexual activity than under the more traditional imposition of purdah.

Finally, it is clear that the presence of working peers, both female and male, socializes garment workers very differently compared with the socialization of girls of the same age who are married and not working. When asked about a group of women with whom they would compare themselves but who were not working, garment workers are most likely to think of girls in school, who, in terms of having similar peer networks, are probably more like garment workers than are married adolescents.

Peer networks are vital to gathering information about wages and availability of jobs in the industry, and to providing information and evaluation of that information about a range of other aspects of life. As may be expected, factories can also be sources of rumor and gossip. For example, two women interviewed from the same factory thought that abortion leads to infertility because one of their co-workers was rumored to have become infertile from repeated abortions. Stories of relations with men are usually reported as gossip heard from other people rather than being presented as personal experiences. 


\section{Transition to adulthood}

In terms of their social status, garment workers are not considered to be full adults, despite their long work days. They are referred to as "girls" whose protection in the workplace is the responsibility of their supervisors, who take the role of guardians in the family (Siddiqi, 1991). Preparing for adult roles that they have not yet assumed but expect to in the near future is an important element of a worker's socialization. Saving for one's own dowry encapsulates elements of a future orientation and also preparation for an adult role. The anticipation of marriage and the preparation for marriageability have the same elements. More importantly, society equates marriage and childbearing with adulthood. These events remain the definitive transition to adulthood for single workers, no matter how delayed.

The introduction of a transitional phase through this particular kind of labor force participation is the first step toward the creation of adolescence. Schlegel (1995) defines adolescence as something more than a transitional phase and includes the rising influence of factors such as the social and personal management of sexuality, the influence of peers and of social organizations, as well as skills and training acquired in the process of work. We have provided some evidence that young female garment workers meet the criteria of experiencing adolescence in these ways.

At the same time, it is probably important for the social transformation effected by garment work that it is viewed as a transitional phenomenon so as not to appear as an inordinate threat to the familiar social order. The views of garment workers themselves echo these sentiments; thus, one worker says about her vision of the future: 
Lily, 16, helper (see Table 3): “Much later, after working for 5-7 years, after learning how to handle a machine and becoming an operator, after saving a lot of money, I want to build a nice house near my parents' house, buy a cow, and buy things for the house. Then I will marry whoever my parents choose for me - I will need to have Tk. 5,000 or 7,000 for the dowry. . . . It's best to marry a boy from your own area ... someone who has passed high school, has a job in an office or as a line chief or supervisor in a garment factory . . . . If the boy is a matric fail (less educated) if his family owns land and a big house, that will be all right too."

Lily thinks it is difficult to continue work after marriage, given the responsibilities of housework, childcare, and other family duties.

\section{Implications for reproductive health}

Garment work has direct implications for reproductive health by enabling girls to delay marriage, and by motivating workers to delay childbearing even when they are married. Although family networks can provide support for childcare, childbearing is nevertheless perceived in terms of lost earning opportunities. Factories are generally unfriendly to the idea of maternity leave provisions or creche facilities and prefer to employ unmarried and/or childless workers. When workers take maternity leave, they often have to reenter the factory as a new employee and thus lose the benefit of previous promotions.

There is some evidence that work allows women to delay marriage. However, the data on marriage delays need to be interpreted with caution 
because marriage is a cause of attrition from work. Table 5 shows that a considerably higher proportion of workers are single compared to nonworking peers of the same age-in the 15-19 age group, 74 percent of workers are single, compared to 64 percent in the sending villages, 45 percent in the non-sending villages and only 29 percent in the non-sending towns. Some of this higher proportion remaining single among workers may be because of marriage-related attrition from work. The higher proportion remaining single in the sending villages relative to non-sending villages is an indication that garment work has legitimized later marriage in workers' communities of origin; although sending villages may have had a delayed pattern of marriage to begin with compared to non-sending villages, it is also likely that the experience of sending young women to work in the city legitimized later

Table 5 Percentage of women never married by age group of workers and non-garment workers

\begin{tabular}{|c|c|c|c|c|c|c|c|c|}
\hline \multirow{3}{*}{$\begin{array}{l}\text { Current } \\
\text { age }\end{array}$} & & & \multicolumn{6}{|c|}{ Non-garment workers } \\
\hline & \multicolumn{2}{|c|}{$\begin{array}{l}\text { Garment } \\
\text { workers }\end{array}$} & \multicolumn{2}{|c|}{$\begin{array}{l}\text { Sending } \\
\text { villages }\end{array}$} & \multicolumn{2}{|c|}{$\begin{array}{c}\text { Non-sending } \\
\text { villages }\end{array}$} & \multicolumn{2}{|c|}{$\begin{array}{c}\text { Non-sending } \\
\text { towns }\end{array}$} \\
\hline & $\%$ & $\mathbf{N}$ & $\%$ & $\mathbf{N}$ & $\%$ & $\mathbf{N}$ & $\%$ & $\mathbf{N}$ \\
\hline $10-14$ & 100 & (97) & 97 & (59) & 88 & $(43)$ & 54 & (13) \\
\hline $15-19$ & 74 & $(438)$ & 64 & $(233)$ & 45 & $(130)$ & 29 & $(93)$ \\
\hline $20-24$ & 24 & $(254)$ & 7 & (124) & 5 & (83) & 12 & $(58)$ \\
\hline $25-29$ & 5 & (93) & 0 & $(60)$ & 0 & (33) & 4 & $(26)$ \\
\hline $30-34$ & 2 & (67) & 0 & $(24)$ & 0 & (16) & 0 & (8) \\
\hline $35+$ & 0 & $(56)$ & 0 & (11) & 0 & (6) & 0 & (4) \\
\hline
\end{tabular}

\section{Notes:}

Data for garment workers (helpers and operators) weighted by occupation, place of residence, and age. Non-garment worker data are unweighted.

See text for explanation of "sending" and "non-sending" areas. 
marriage. Table 6 shows that only 31 percent of 20-24-year-old and 29 percent of 25-29-year-old garment workers who were not married before entry into work were married by the age of 18 . Garment work seems to reduce marriage not only at very young ages but also beyond the age of 20. Only 56 percent of garment workers aged 20-24 were married by the age of 20, compared to 83 percent of women in sending villages, 92 percent of women in non-sending villages, and 86 percent in the non-sending towns.

Table 6 Percentage of women who married early by current age group: Garment workers and non-garment workers

\begin{tabular}{cc} 
Garment workers \\
\hline $\begin{array}{c}\text { Married } \\
\text { after }\end{array} \begin{array}{c}\text { Married } \\
\text { before }\end{array}$
\end{tabular}

Current beginning beginning

age work work

$\%$ of women who married by exact age 18 :

20-24

31

79

67

61

66

25-29

29

71

84

30-34

a

82

91

$35+$

a

71

81
Non-garment workers

Sending Non-sending Non-sending villages villages towns

78

65

88

$\%$ of women who married by exact age 20 :

20-24

56

96

83

92

86

25-29

50

80

90

91

81

30-34

a

72

71

94

100

$35+$

a

82

100

100

100

Notes:

Data for garment workers (helpers and operators) weighted by occupation, place of residence, and age. Non-garment worker data are unweighted.

See text for explanation of "sending" and "non-sending" areas.

a: number of cases too low for meaningful estimate. 
Workers typically want two children, one girl and one boy with considerable spacing in between. Bangladesh is experiencing a rapid transformation to small family-size norms: a recent analysis shows that wanted fertility in Bangladesh is 2.1 children, lower in than in any other country in South Asia (Bongaarts and Amin, 1997). In this environment of low familysize norms, it is not surprising that garment workers hold the same preferences. What is apparently different about garment workers is their ability to implement delayed childbirth much more than non-garment working women. Workers are more likely to state specific reasons that motivate them to desire small families: these are articulated as high aspirations for child's education or cost of living in terms of higher rents.

\begin{abstract}
Aleya, 20-year-old-single operator: "It's best if you have one son and one daughter, but in case you have two of either sex you still should not go for a third. I am confident that I can convince whoever I marry why it is important that you should stop at two. (You see) men don't think, which is why they don't understand these things, and you just have to be patient and explain things to them. For instance, a woman has to explain to her man that they have to use contraception from the very first day of marriage."
\end{abstract}

Table 7 includes several quotes that contrast responses to similar questions about ideal family size included in the present survey and in a village study conducted by one of the authors (Amin, 1996). While the statements about ideal family size are similar, the level of agency and motivation reflected by workers is strong, while rural, nonworking respondents convey more fragile motivations and greater passivity about attaining family-size goals. 
Table 7 Statements made by young Bangladeshi women about desired family size

Garment Workers in Dhaka, 1996

Padma, 17, married garment worker: "If you take the pill or get an MR you might never be able to get pregnant again. ... I will have one now and another 5-7 years later and will not take more than two. Because the way population is growing in the country, it is not good to take more than two. I heard this on the radio and TV. If you keep having kids landlords will not rent to you."

Parul, 23, engaged: "I want one son and one daughter." (Prompted: what if your husband wants more?) "I'll still have only two: he is not the only one entitled to an opinion."

Shireen, 17, single: "I will take into consideration how many my husband wants, but if he wants too many I will not go along with it."
Rural Respondents in Rajshahi, 1995-96

Shadi, 23 married: "I want to take one child but he (husband) wants two. Two is enough. At the moment we are not using any contraception."

As may be expected for unmarried respondents, discussing knowledge or use of contraception is difficult because of the implications of sexual activity. Nevertheless, it is evident that these women have been exposed to information about contraception from the media and from their married friends and relatives. In general, responses to questions about where services are available and what workers do in cases of illness revealed that urban workers are more likely to mention going to a doctor, health center, and pharmacy rather than being visited by outreach workers, which is more typical for rural respondents (Salway, 1996). In the quantitative survey of garment workers, 80 percent of unmarried adolescents were able to state at least one source for obtaining contraception. 
Discussions with health service providers also suggested that garment workers may be under greater pressures for early sexual activity outside marriage relative to single girls who are not working. Our informants in the health sector reported that even single workers are concerned about pregnancy when they visit a health care provider with irregular menstruation. Increased exposure to sexual activity may simply be a result of the long hours that young men and women spend in one another's company unsupervised by parents and guardians. Nevertheless, the social sanctions against sexual activity are strong and many workers are uncomfortable with the pressures they face in the factory:

Padma, 17-year-old married operator: "There are some problems at work ... a lot of men like to flirt with the girls and tease them.... They pinch the girls, touch their hands, press their breasts. They do it when the electricity goes off. ... Some girls don't like that and they complain to the supervisor."

Thus, while there is little direct evidence of premarital sexual activity, health service providers argue there is a special need for education and services for reproductive health for garment workers. These needs arise for reasons of higher exposure to risk of sexual activity as well as inadequate access to information. In the absence of special services, peer networks will probably continue to be the primary source of information for garment workers. These networks may be less reliable than most traditional informal networks because the workers are all around the same age and many are not married. Living in an urban area with higher standards of living, workers 
may have better access to media, but because they are not married they have less access to confidential professional services or even to grandmothers, mothers, and brothers' wives living nearby. As shown in an earlier section, some of the information exchanged by garment workers may be incorrect, for instance the belief that abortion may lead to infertility or that women in some families take longer to conceive than others and thus do not need to use contraception. Since many women leave the garment industry upon marriage but are very open to information while still working, it is particularly important that health care providers extend their services, particularly IEC services, to unmarried garment workers.

\section{CONCLUSION}

The central argument of this paper is that garment work creates an interval of adolescence in a way that women could not otherwise have expected. The ability of young women to remain in their parents' household during their transition to adulthood, and at the same time achieve some level of independence by working outside the home and generating their own income, leads to a radically different socialization from the traditional pattern of early marriage and childbearing. In working outside the home, women use familial and social networks to gain entry to and subsequently develop new peer networks that act as sources of information and support.

An essential part of the socialization related to work is to negotiate the various ways society stigmatizes working women, presenting constraints to women in their quest for autonomy, while at the same time valuing their economic contributions. The factory represents an important place for a new 
kind of socialization - the nature of work is viewed as technological and sophisticated and, therefore, superior to most alternatives. The labor force is differentiated in terms of status and earnings, allowing women to set goals for advancement. Co-workers form an important peer group. Workers form groups to save in rotating funds; they travel to and from work together; and they rely on peers for information and evaluation regarding alternative opportunities and even regarding marriage prospects.

The presence of peers has implications for young women's reproductive health, as does the increased pressure for sexual activity that accompanies the greater mobility and autonomy of women and their interactions with men. However, the overarching reproductive health implication of working is that it allows women to delay marriage and, even after marriage, to delay births, because of the high opportunity costs to women of leaving the workforce.

All these outcomes of garment work that may be regarded as beneficial have largely been experienced by women who have entered garment work as teenagers; many of them are so young that, according to official definitions, their activities would be considered child labor and illegal. However, given the extremely limited choices faced by the households from which these workers come, for whom education is rarely a realistic option, entry into garment work may be regarded as a positive opportunity by helping to delay marriage and reducing the need for entry into alternative and more risky forms of employment.

\section{Notes}

1. Female supervisors have not been included in the current analysis so as not to overrepresent such a select group. 
2. It should be noted that only 11 percent of respondents in our survey live in slums. The informant uses the word slum to indicate lowerclass housing areas more generally.

3. 1 US $\$=43$ Taka.

\section{References}

Amin, Sajeda. 1996. "Female education and fertility in Bangladesh: The influence of marriage and the family," in Roger Jeffery and Alaka M. Basu (eds.), Girls'Schooling, Women's Autonomy and Fertility Change in South Asia, pp. 184-204. New Delhi, London, Thousand Oaks: Sage Publications.

Amin, Sajeda. 1997. "The poverty-purdah trap in rural Bangladesh: Implications for women's roles in the family," Development and Change 28, no. 2: 213-233.

Amin, Sajeda. Forthcoming. "Family structure and change in rural Bangladesh," Population Studies.

Aziz, K.M. Ashraful and Clarence Maloney. 1985. Life Stages, Gender and Fertility in Bangladesh. Dhaka: International Centre for Diarrhoeal Disease Research, Bangladesh.

Bangladesh Garment Manufacturers and Exporters Association (BGMEA). 1995. BGMEA Members' Directory: 1995. Dhaka: BGMEA.

Basu, Alaka M. 1992. Culture, the Status of Women and Demographic Behavior: Illustrated with the Case of India. Oxford: Clarendon Press.

Basu, Kaushik. 1994. "The poor need child labor," Op-ed, New York Times, 29 November.

Bhattacharya, Debapriya. 1996. "International trade, social labelling and developing countries: The case of Bangladesh's garments export and use of child labor," Bangladesh Institute of Development Studies, unpublished manuscript. 
Bongaarts, John and Sajeda Amin. 1997. "Prospects for fertility decline and implications for population growth in South Asia," Policy Research Division Working Paper No. 94. New York: Population Council.

Cain, Mead T. 1977. "The economic activities of children in a village in Bangladesh," Population and Development Review 3, no. 3: 201-227.

Casterline, John and T. James Trussell. 1980. "Age at first birth," Comparative Studies: Cross National Summaries, No. 15. International Statistical Institute: World Fertility Survey.

Christerson, Brad and Richard P. Appelbaum. 1995. "Global and local subcontracting: Space, ethnicity, and the organization of apparel production," World Development 23, no. 8: 1,363-1,374. Great Britain: Pergamon-Elsevier Science Limited.

De Tray, Dennis. 1983. "Children's work activities in Malaysia," Population and Development Review 9, no. 3: 437-455.

Findley, Sally E. and Lindy Williams. 1991. "Women who go and women who stay: Reflections of family migration processes in a changing world," World Employment Programme Research Working Paper No. 176. Geneva: International Labor Office.

Government of Bangladesh. 1978. World Fertility Survey: Bangladesh Fertility Survey: 1975. Dhaka: Ministry of Health and Population Control.

Hennink, Monique. 1997. "Family planning services for people with special needs," unpublished Ph.D. dissertation. Southampton, UK: University of Southampton.

Huq, Mohammed Najmul and John Cleland. 1990. Bangladesh Fertility Survey 1989 (Main Report). Dhaka: National Institute of Population Research and Training (NIPORT). 
Jain, Devaki. 1985. "The household trap: Report on a field survey of female activity patterns," in D. Jain and N. Bannerjee (eds.), Tyranny of the Household: Investigative Essays on Women's Work, pp. 215-249. Delhi: Shakti Books.

Kabeer, Naila. 1991. "Cultural dopes or rational fools: Women and labor supply in the Bangladesh garment industry," The European Journal of Development Research 3, no. 4: 133-160. London: Frank Cass and Company Limited.

Kibria, Nazli. 1995. "Culture, social class and income control in the lives of women garment workers in Bangladesh," Gender and Society 9, no. 3: 289-309.

Kibria, Nazli. 1996. "Becoming a garments worker: The mobilization of women into the garments factories of Bangladesh," paper presented at the United Nations Research Institute for Social Development and Centre for Policy Dialogue, an International Workshop on Working Towards a More Gender Equitable Macro-Economic Agenda, 26-28 November, BRAC Conference Centre, Rajendrapur, Bangladesh.

Mitra, S.N. et al. 1994. Bangladesh Demographic and Health Survey 1993 94. Calverton, MD: National Institute of Population Research and Training (NIPORT), Mitra and Associates, and Macro International.

Nag, Moni, Benjamin N.F. White, and Robert Creighton Peet. 1977. “An anthropological approach to the study of economic value of children in Java and Nepal," Center for Policy Studies Working Paper. New York: Population Council.

Paul-Majumdar, Protima and Salma Chowdhuri Zohir. 1994. "Dynamics of wage employment: A case of employment in the garment industry," in Sajeda Amin (ed.), Special Issue on Women, Development and Change, Bangladesh Development Studies 22, nos. 2 and 3: 179-216. 
Salway, Sarah. 1996. "Contraception following childbirth in Bangladesh," unpublished Ph.D. dissertation. London: University of London.

Schlegel, Alice. 1995. "A cross-cultural approach to adolescence," in Alice Schlegel (guest editor), Special Issue on Adolescence, Ethos: Journal of the Society for Psychological Anthropology 23, no. 1.

Siddiqi, Dina M. 1991. "Discipline and protect: Women factory workers in Bangladesh," Grassroots: An Alternative Development Journal 1, no. 2.

Simmons, Ruth, Rezina Mita, and Michael A. Koenig. 1992. "Employment in family planning and women's status in Bangladesh," Studies in Family Planning 23, no. 2: 97-109.

Smith, David. 1980. "Age at first marriage," WFS Comparative Studies No. 7. London.

Standing, Guy. 1989. "Global feminization through flexible labor," World Development 7, no. 7: 1077-1096.

United Nations. 1995a. The World's Women 1995. Social Statistics and Indicator Series K, No. 12. New York.

United Nations, 1995b. Women's Employment and Fertility: A Comparative Analysis of World Fertility Survey Results for 38 Developing Countries, Department of International Economic and Social Affairs/ Population Studies, No. 96. New York: United Nations.

White, Ben. 1994. "Children, work and 'child labour': Changing responses to the employment of children," Development and Change 25: 849878. 


\title{
POLICY RESEARCH DIVISION WORKING PAPERS
}

\author{
Recent Back Issues
}

\section{5}

* 70 Sajeda Amin, John Cleland, James F. Phillips, and Gholam Mostafa Kamal, "Socioeconomic change and the demand for children in rural Bangladesh."

71 John Bongaarts, "The role of family planning programs in contemporary fertility transitions."

72 Geoffrey McNicoll, "On population growth and revisionism: Further questions."

73 James F. Phillips, Mian Bazle Hossain, and Mary Arends-Kuenning, "The longterm demographic role of communitybased family planning in rural Bangladesh."

74 Cynthia B. Lloyd, "Household structure and poverty: What are the connections?"

75 Sajeda Amin, "The poverty-purdah trap in rural Bangladesh: Implications for women's roles in the family."

76 Martin Brockerhoff, "Child mortality in East Africa: The impact of preventive health care."
77 Thomas K. LeGrand and James F. Phillips, "The effect of fertility reductions on infant and child mortality: Evidence from Matlab in rural Bangladesh."

78 Cynthia B. Lloyd and Ann K. Blanc, "Children's schooling in sub-Saharan Africa: The role of fathers, mothers, and others."

79 Geoffrey McNicoll, "Demography in the unmaking of civil society."

80 John Bongaarts, "Global trends in AIDS mortality."

81 Barbara Mensch, Mary ArendsKuenning, Anrudh Jain, and María Rosa Garate, "Meeting reproductive goals: The impact of the quality of family planning services on unintended pregnancy in Peru."

82 Mark Montgomery, Aka Kouamé, and Raylynn Oliver, "The tradeoff between the number of children and their schooling: Evidence from Côte d'Ivoire and Ghana."
83 Sajeda Amin, Ian Diamond, and Fiona Steele, "Contraception and religious practice in Bangladesh."
84 John B. Casterline, Aurora E. Perez, and Ann E. Biddlecom, "Factors underlying unmet need for family planning in the Philippines."

* No longer available 
85 Geoffrey McNicoll, "Governance of fertility transition: Regularity and duress."

86 John Bongaarts, "Population pressure and the food supply system in the developing world."

87 Sajeda Amin, "Family structure and change in rural Bangladesh."

88 John Bongaarts and Susan Cotts Watkins, "Social interactions and contemporary fertility transitions."

89 Cynthia B. Lloyd and Mark R. Montgomery, "The consequences of unin- tended fertility for investments in children: Conceptual and methodological issues."

* 90 Zeba Sathar and Sonalde Desai, "Work patterns in rural Pakistan: Intersections between gender, family, and class."

* 91 Mark R. Montgomery, "Learning and lags in mortality perceptions."

92 Ann E. Biddlecom, John B. Casterline, and Aurora E. Perez, "Men's and women's views of contraception."
93 James F. Phillips, Fred N. Binka, Martin Adjuik, Alex Nazzar, and Kubaze Frank Adazu, "The determinants of contraceptive innovation: A case-control study of family planning acceptance in a traditional African society."

94 John Bongaarts and Sajeda Amin, "Prospects for fertility decline and implications for population growth in South Asia."

95 Barbara S. Mensch and Cynthia B. Lloyd, "Gender differences in the schooling experiences of adolescents in low-income countries: The case of Kenya."

96 Martin Brockerhoff and Ellen Brennan, "The poverty of cities in the developing world."

* No longer available
97 Carol E. Kaufman, "Reproductive control in South Africa."

98 John Bongaarts, "Trends in unwanted childbearing in the developing world."

99 Mary Arends-Kuenning, "How do family planning workers' visits affect women's contraceptive behavior in Bangladesh?"

100 Mark R. Montgomery and Cynthia B. Lloyd, "Excess fertility, unintended births, and children's schooling."

101 Mary Arends-Kuenning, "The equity and efficiency of doorstep delivery of contraceptives in Bangladesh."

102 Sajeda Amin, Ian Diamond, Ruchira T. Naved, and Margaret Newby, "Transition to adulthood of female factory workers: Some evidence from Bangladesh." 